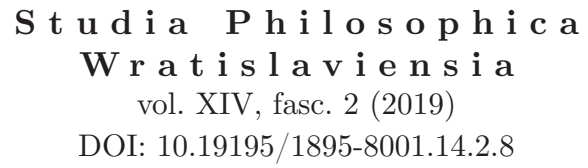

WALTER BENJAMIN

\title{
Paryż — miasto w zwierciadle. Wyznania miłosne pisarzy i artystów wobec „,stolicy świata"
}

Spośród wszystkich miast nie ma żadnego, które byłoby tak silnie związane z książką jak Paryż. Jeśli Giraudoux ma rację i przechadzanie się wraz z biegiem rzeki wywołuje najwyższe znane ludziom uczucie wolności, to najdoskonalsze próżniactwo oraz najmilsza swoboda również związane są z książką i z niej wynikają. Na gołych nabrzeżach Sekwany przez wieki kładł się bluszcz uczonych liści — dlatego Paryż jest ogromną biblioteczną czytelnią, przez którą przepływa Sekwana.

Nie ma w tym mieście zabytku, którym nie inspirowałoby się jakieś arcydzieło literatury pięknej. Notre Dame przywodzi na myśl powieść Victora Hugo. Wieża Eiffla — „Młodych małżonków z wieży Eiffla” Cocteau, a wraz z „Modlitwą na wieży Eiffla" Giraudoux osiągamy zawrotny już poziom najnowszej literatury. Opera: dzięki słynnej powieści detektywistycznej Leroux „Upiór w operze” znajdujemy się w podziemiach tego budynku i literatury jednocześnie. Łuk tryumfalny pręży się nad ziemią wraz z "Grobem nieznanego żołnierza” Raynala. Miasto wpisało się w literaturę tak trwale, ponieważ kieruje nim duch zamieszkujący książki. Czyż nie przygotowywało z góry, niczym wprawny pisarz, najistotniejszych motywów swojej struktury? Takich jak szerokie drogi wojskowe, które dawniej miały zabezpieczać dojście żołnierzy do Paryża od Porte Maillot, Porte de Vincennes, Porte de Versailles. I pewnego ranka, przez noc, Paryż stał się posiadaczem najlepszych autostrad ze wszystkich miast Europy. Oto wieża Eiffla — czysty, wolny pomnik techniki w duchu sportowym, a później, niespodziewanie, europejska radiostacja. Ponadto nieprzewidywalnie puste place: czyż nie są niczym wykwintne karty, całostronicowe ilustracje w tomach historii świata? Lśnią czerwone cyfry roku 1789 na Place de Grèves. Dachy otaczają z każdej strony załomami Place des Vosges, na którym poniósł śmierć Henryk II. Wytarte zarysy nieczytelnego pisma na Place Maubert, niegdyś bramy prowadzącej do mrocznego Paryża. We wzajemnym oddziaływaniu 
między miastem a książką jeden z tych placów zawędrował do bibliotek: na słynnych drukach Diderota z ubiegłego wieku tkwi Place du Panthéon niczym sygnet.

Gdyby spektrum literackie miasta ująć w formę oszlifowanego pryzmatu, to im dalej od jego środka i bliżej krawędzi, tym książki wyglądają osobliwiej. Ultrafioletowej i podczerwonej znajomości tego miasta - jego fotografii i planu, najdokładniejszej wiedzy od szczegółu do ogółu — nie da się już zawrzeć w formie książki. Z perspektywy tych najdalszych krawędzi czerpiemy najpiękniejsze okazy. Kto musiał kiedykolwiek na rogu ulicy obcego miasta radzić sobie przy złej pogodzie z jednym z rozłożystych papierowych planów, które, przy byle podmuchu wiatru, nadymają się jak żagiel, rozrywając się na każdej krawędzi i stając się wkrótce jedynie sprawiającą nam kłopot stertą brudnych kart, doświadcza ze studiowania planu Taride'a ${ }^{1}$, czym może być plan miasta. I czym jest miasto. Dzielnice odsłaniają bowiem swoje sekrety w nazwach ulic. Na rozległym placu przed Dworcem Saint-Lazare otacza nas połowa Francji i Europy. Nazwy takie jak Hawr, Anjou, Prowansja, Rouen, Londyn, Amsterdam, Konstantynopol ciągną się szarymi ulicami niczym opalizujące wstążki przez szare jedwabie. To tak zwana Dzielnica Europejska. Można przemierzać w ten sposób ulice na mapie kawałek po kawałku, czy też „ulicę po ulicy, dom po domu” — jak głosi obszerne dzieło, w którym dworski historyk Napoleona III Lefeuve zebrał w połowie XIX wieku wszystko, co warte poznania. Już tytuł pracy daje wyobrażenie o tym, co może odnaleźć w niej ten, kto się z nią zapozna, czy też próbuje jedynie przewertować sto kart pod hasłem „Paryż” w zamkniętym od 1867 roku katalogu Biblioteki Cesarskiej. Nie należy spodziewać się tam samych pism naukowych, archiwalnych, topograficznych czy historycznych — wyznania miłości wobec „stolicy świata” nie stanowią wcale najmniejszej części tej masy książek. Fakt, że są one głównie autorstwa obcych, nie jest niczym nowym. Prawie zawsze najżarliwsi wielbiciele tego miasta pochodzą spoza jego granic, a ich sieć rozciąga się na całej ziemi. Jest wśród nich Nguyen-Trong-Hiêp, który opublikował w 1897 roku w Hanoi wiersz pochwalny o francuskiej stolicy. A także, by wspomnieć tylko o najmłodszych, rumuńska księżniczka Bibesco, której czarująca Catherine-Paris, chcąc wrócić do ojczyzny, unika galicyjskich zamków, polskiej wysokiej arystokracji, swego małżonka, hrabiego Leopolskiego. Wydaje się, że w rzeczywistości pod postacią Leopolskiego kryje się Adam Czartoryski. W Polsce ta książka nie spotkała się ze zbyt dużą miłością... Nie wszyscy wielbiciele składali jednak miastu u stóp swe uwielbienie w postaci powieści czy wiersza: niedawno Mario von Bucovich dał piękny i wiarygodny wyraz swojej sympatii poprzez fotografię, a Morand przypieczętował to uczucie w przedmowie do albumu.

Miasto odzwierciedla się w tysiącu oczu, tysiącu obiektywów. Nie tylko bowiem niebo i atmosfera czy świetlne reklamy na wieczornych bulwarach uczyniły z Paryża „miasto światła”. Paryż jest miastem luster: asfalt jego ulic lśni niczym zwierciadło. Przed każdym bistro szklane ścianki: kobiety przeglądają się w nich częściej niż gdziekolwiek indziej. Z tych luster wyłania się uroda paryżanek. Zanim

${ }^{1}$ Alphonse Taride (1850-1918) — paryski wydawca publikujący mapy, plany miast i rejonów Francji oraz przewodniki turystyczne. 
ktokolwiek na nie spojrzy, zdążą sprawdzić już dziesięć zwierciadeł. Obfitość luster obejmuje również mężczyznę, zwłaszcza w kawiarni (aby ją rozjaśnić i nadać wszystkim drobnym zakamarkom i wnękom, na jakie dzielą się paryskie lokale, satysfakcjonującą przestrzenność). Lustra są duchowym elementem tego miasta, jego herbem, w który trwale wrysowały się emblematy wszystkich szkół literackich.

Podobnie jak powstające natychmiast w lustrze odbicie (w tym przypadku symetrycznie odwrócone), tak również w technice słów kluczowych Marivaux zwierciadło rzuca ruchliwą przestrzeń zewnętrzną, ulicę, we wnętrze kawiarni - upodobali to sobie Hugo i Vigny, chcący uchwycić charakter środowiska i umieścić swe opowieści na „historycznym tle”.

Wiszące w knajpach brudne i zaniedbane lustra są symbolem naturalizmu Zoli; tworzą wspólnie nieprzerwaną serię wzajemnych odbić, czego odpowiednikiem jest niekończąca się pamięć pamięci, w którą zmieniło się pod piórem Marcela Prousta jego własne życie. Najnowszą serię zdjęć zatytułowaną „Paryż” zamyka ujęcie Sekwany. Jest ona dużym, zawsze czujnym lustrem Paryża, który każdego dnia rzuca do tej rzeki w postaci obrazów swoje solidne budynki i obłoki ze snów. Przyjmuje swe ofiary łagodnie i na znak życzliwości łamie na tysiące kawałków.

Przekład i komentarz: Mateusz Palka 